\title{
GAMBARAN KELENGKAPAN DAN KESERAGAMAN PENULISAN ODONTOGRAM OLEH DOKTER GIGI DI KOTA SEMARANG
}

Moh. Yusuf ${ }^{\star}$ Syuhada Setiawan ${ }^{\star *}$, Andina Rizkia Putri Kusuma***

Keywords:

Odontograms filling

out, incomplete and

unequal odontogram

Dentist, Semarang

city

\section{ABSTRACT}

Background: Odontogram is one part of the dental record. The odontogram form is filled with diagnoses and treatment done by the dentist. Odontogram can be used for the further treatment plan and help the forensic department to do the identification. The purpose of this study was to identify the completeness of odontogram filling out by the dentist in Semarang.

Method: The research was descriptive using a cross-sectional study design. The subject of the research was graduated dentist in year 2015 until 2017. Subjects were chosen through information from PDGI.

Result: The result of this study showed that none of the subjects filled odontogram completely, 5 subjects filled less complete and 39 others were categorized incomplete according to medical record guidance book published in 2015.

Conclusion: Based on the study, concluded that the need to pay attention about the importance of filling odontogram by the dentist was still low.

\section{PENDAHULUAN}

Dokter dan Dokter gigi memiliki peranan penting dalam pemberian pelayanan kesehatan dan mutu pelayanan bagi masyarakat. Dokter dan Dokter gigi harus mengacu pada standar, pedoman dan prosedur yang berlaku, sehingga dapat memberikan pelayanan medis yang profesional dan aman bagi masyarakat ${ }^{1}$. Salah satu hal yang diatur dalam UU praktik kedokteran adalah tentang rekam medis, yang tertuang pada pasal 46 dan 47. kewajiban dan tanggung jawab atas kelengkapan dan keakurasian pengisian rekam medis melekat pada Dokter atau dokter gigi yang merawat pasien².

Pembuatan rekam medik oleh dokter pada kartu pasien sebenarnya telah menjadi kebiasaan sejak jaman dahulu, namun belum menjadi kewajiban, sehingga pelaksanaanya tidak begitu serius. Seiring dengan berkembangnya jaman masyarakat pun menjadi dinamis, maka rekam medik menjadi penting. Pemerintah Indonesia melalui departemen kesehatan mengeluarkan peraturan menteri kesehatan nomer 749a/MENKES/ Per/XII/1989 tentang RM/Medical record. Dengan diterbitkannya PERMENKES, pengadaan rekam medis telah menjadi hukum yang harus di taati bagi setiap sarana pelayanan kesehatan ${ }^{3}$.

Odontogram berperan penting dalam penyempurnaan rekam medik. Odontogram, memuat pemeriksaan seluruh gigi dan mulut yang dapat memberikan gambaran keadaan gigi dan mulut. Odontogram harus dibuat secara teliti sehingga dapat di bedakan dan di ketahui secara pasti keadaan gigi dan jenis tindakan yang akan dilakukan. Data odontogram juga dapat menjadi tolak ukur apakah suatu wilayah tersebut telah berhasil dalam mengupayakan kesehatan gigi dan mulut di masyarakat sekitar ${ }^{4}$.

Susunan gigi tidak berbeda jauh dengan si-

*Departemen Radiologi dan Forensik Kedokteran Gigi Fakultas Kedokteran Gigi Universitas Islam Sultan Agung Semarang, ${ }^{* *}$ Program Sarjana Kedokteran Gigi Fakultas Kedokteran Gigi Universitas Islam Sultan Agung Semarang,

***Departemen Konservasi Gigi Fakultas Kedokteran Gigi Universitas Islam Sultan Agung Semarang

Korespondensi: mohyusuf@unissula.ac.id 
dik jari, setiap individu memiliki sidik jari yang berbeda-beda, maka sama halnya dengan susunan gigi, setiap individu memiliki susunan gigi yang berbeda-beda. Semaksimal mungkin mencatat odontogram secara teliti mengenai keadaan gigi dan terapi yang akan dilakukan, sehingga keadaan gigi dan tindakan yang dilakukan dapat diketahui dan dibedakan secara pasti ${ }^{5}$.

Gigi dapat dipakai sebagai sarana identifikasi karena gigi adalah bagian terkeras dari tubuh manusia yang komposisi organik dan airnya sedikit sekali dan bahan anorganik yang besar sehingga tidak mudah rusak, selain itu juga terlindungi dari tempatnya sendiri yang berada di dalam mulut dan dilingkupi dengan basahnya air liur. Gigi dapat lapuk pada keadaan suhu 200 dan menjadi abu pada keadaan suhu 450 . Dapat diketahui informasi mengenai berbagai variasi keadaan gigi, baik yang sehat, ditambal, dicabut, gigi tiruan, implant dan lain-lain. Sehingga identifikasi terhadap korban bisa dilakukan ${ }^{6}$.

Dokter Gigi wajib membuat rekam medis dan melakukan pengisian odontogram pada kunjungan pertama. Manfaat diberlakukannya hal tersebut,dapat membantu sejawat lainnya dalam melakukan tindakan, dapat membantu dalam penyelesain masalah hukum, disiplin dan etik maupun untuk kepentingan identifikasi jika pasien mengalami musibah. Hingga saat ini dikalangan parktisi Kedokteran Gigi memiliki hambatan keseragaman cara penulisan nomenklatur gigi maupun istilah catatan yang digunakan untuk mencatat tindakan medis yang dilakukan, sehingga masih timbul keraguan saat rekam medis dibaca oleh sejawat lainnya ${ }^{7}$. Tujuan penelitian ini adalah mengetahui kelengkapan dan keseragaman penulisan odontogram Dokter gigi di Kota Semarang.

\section{METODE PENELITIAN}

Penelitian ini merupakan penelitian deskriptif dengan rancangan non eksperimental (observasional) yaitu cross-sectional study. Ethical clearance diperoleh dari komisi etik penelitian FKG UNISSULA No. 068/B.1-KEPK/ SA-FKG/XI/2018. Populasi pada penelitian ini adalah Dokter Gigi Iulusan tahun 2015-2017 yang telah terdaftar di PDGI Semarang sejumlah 80. Besar sampel minimal yang akan diambil menggunakan rumus Slovin.

Sampel pada penelitian ini didapatkan 44 odontogram Dokter gigi yang memenuhi kriteria inklusi. Pengambilan sampel menggunakan teknik simple random sampling. Setiap unit populasi memiliki kesempatan yang sama untuk diambil sebagai sampel yang akan dilakukan penilaian kelengkapan dan keseragaman odontogramnya. Penilaian odontogram dilakukan dengan cara menilai ketentuan umum penulisan odontogram, ketentuan khusus penulisan odontogram, singkatan penulisan odontogram, simbol-simbol odontogram dan penilaian terdapat nama, tanda tangan, tanggal pemeriksaan.

\section{HASIL PENELITIAN}

Berdasarkan tabel 1. hasil penulisan odontogram Dokter gigi di kota semarang didapatkan penulisan odontogram Dokter gigi secara tidak lengkap sebesar $89 \%$ atau sebanyak 39 responden Dokter gigi. Penulisan odontogram Dokter gigi masuk dengan kategori kurang lengkap sebesar $11 \%$ atau sebanyak 5 responden. Penelitian yang didapatkan tidak menemukan penulisan odontogram Dokter gigi masuk kategori lengkap.

Berdasarkan tabel 2. penilaian ketentuan umum didapatkan 41 responden Dokter gigi 
Tabel 1. Hasil Odontogram Dokter Gigi di Kota Semarang

\begin{tabular}{ccccc}
\hline & \multicolumn{4}{c}{ Penulisan odontogram Dokter gigi } \\
\cline { 2 - 5 } & $\begin{array}{c}\text { Tidak } \\
\text { lengkap }\end{array}$ & $\begin{array}{c}\text { Kurang } \\
\text { lengkap }\end{array}$ & lengkap & Total \\
\hline $\begin{array}{c}\text { Penilaian penulisan } \\
\text { odontogram Dokter gigi }\end{array}$ & 39 & 5 & 0 & 44 \\
\hline
\end{tabular}

Tabel 2. Penilaian ketentuan umum penulisan odontogram

\begin{tabular}{cccc}
\hline \multirow{2}{*}{$\begin{array}{c}\text { Penilaian ketentuan } \\
\text { umum }\end{array}$} & \multicolumn{3}{c}{ Penulisan odontogram Dokter gigi } \\
\cline { 2 - 4 } & Melakukan & Tidak melakukan & Total \\
\hline $\begin{array}{c}\text { Penulisan } \\
\text { menggunakan FDI }\end{array}$ & 41 & 3 & 44 \\
$\begin{array}{c}\text { Penulisan singkatan } \\
\text { MODVL }\end{array}$ & 2 & 42 & 44 \\
$\begin{array}{c}\text { Penulisan simbol } \\
\text { restorasi }\end{array}$ & 3 & 41 & 44 \\
\hline
\end{tabular}

Tabel 3. Penilaian ketentuan khusus penulisan odontogram

\begin{tabular}{lccc}
\hline \multirow{2}{*}{ Penilaian ketentuan khusus } & \multicolumn{3}{c}{ Penulisan odontogram Dokter gigi } \\
\cline { 2 - 4 } & Melakukan & Tidak melakukan & Total \\
\hline $\begin{array}{l}\text { 1. Singkatan lokasi/posisi } \\
\text { caries dengan capital }\end{array}$ & 2 & 42 & 44 \\
2. Singkatan kondisi lain & 2 & 42 & 44 \\
3. Tanda (-) & 2 & 42 & 44 \\
$\begin{array}{l}\text { 4. Keterangan tambahan } \\
\text { ("...........") }\end{array}$ & 0 & 44 & 44 \\
\hline
\end{tabular}

Tabel 4. Penilaian singkatan penulisan odontogram

\begin{tabular}{lccc}
\hline & \multicolumn{3}{c}{ Penulisan odontogram Dokter gigi } \\
\cline { 2 - 4 } & Sudah sesuai & Belum sesuai & Total \\
\hline $\begin{array}{c}\text { Penilaian singkatan } \\
\text { odontogram }\end{array}$ & 2 & 42 & 44 \\
\hline
\end{tabular}

menulis odoontogram sesuai dengan poin nomer 1. Penulisan odontogram yang sesuai dengan penilaian ketentuan umum poin nomer 2 didapatkan hanya 2 responden. Penilaian ketentuan umum pada odontogram yang ses- uai dengan poin nomer 3 didapatkan sebanyak 3 responden.

Berdasarkan tabel 3. penilaian ketentuan khusus didapatkan 2 responden Dokter gigi menulis odontogram sesuai dengan poin no- 
Tabel 5. Penilaian simbol-simbol odontogram

\begin{tabular}{cccc}
\hline & \multicolumn{3}{c}{ Penulisan odontogram Dokter gigi } \\
\cline { 2 - 4 } & Sudah sesuai & Belum sesuai & Total \\
\hline $\begin{array}{c}\text { Penilaian simbol- } \\
\text { simbol odontogram }\end{array}$ & 8 & 36 & 44 \\
\hline
\end{tabular}

Tabel 6. Penilaian odontogram lainnya

\begin{tabular}{cccc}
\hline $\begin{array}{c}\text { Penilaian } \\
\text { odontogram } \\
\text { lainya }\end{array}$ & Melakukan & Tidak melakukan & Total \\
\cline { 2 - 4 } & 13 & 31 & 44 \\
\hline $\begin{array}{c}\text { Terdapat nama } \\
\text { Dokter }\end{array}$ & 15 & 29 & 44 \\
$\begin{array}{c}\text { Tanda tangan } \\
\text { Dokter }\end{array}$ & 44 & 0 & 44 \\
$\begin{array}{c}\text { Tanggal } \\
\text { pemeriksaan }\end{array}$ & 44 . & & \\
\hline
\end{tabular}

mer 1 , poin nomer 2 dan poin nomer 3 . Penilaian ketentuan khusus tidak didapatkan odontogram responden Dokter gigi yang sesuai dengan poin nomer 4 .

Berdasarkan 4. penilaian singkatan penulisan odontogram didapakan sebesar 95\% responden Dokter gigi penulisan singkatan odontogramnya masih tidak sesuai. Responden Dokter gigi yang sesuai menulis singkatan penulisan odontogram hanya sebesar $5 \%$ dari 44 responden.

Berdasarkan tabel 5. penilaian simbol-simbol odontogram didapatkan sebesar $82 \%$ atau 36 responden Dokter gigi simbol-simbol odontogramnya masih tidak sesuai. Responden Dokter gigi yang sesuai membuat simbol-simbol odontogram hanya sebesar $18 \%$ atau 8 responden.

Berdasarkan tabel 6. penilaian odontogram lainnya didapatkan 13 responden Dokter gigi menulis odoontogram sesuai dengan poin nomer 1. Penulisan odontogram yang sesuai dengan penilaian odontogram lainnya poin nomer 2 didapatkan 15 responden. Penilaian odontogram lainnya pada odontogram yang sesuai dengan poin nomer 3 didapatkan sebanyak 44 responden.

\section{DISKUSI}

Hasil penelitian ini didapatkan penulisan odontogram Dokter gigi didominasi penulisan odontogram yang masuk kategori tidak lengkap sebesar $89 \%$ atau sebanyak 39 responden Dokter gigi. Penilaian ketentuan umum nomer 1 menjadi paling banyak responden Dokter gigi yang telah melakukan yaitu, sebanyak 41 responden. Penilaian ketentuan khusus nomer 1, 2 dan 3 didapatkan hanya 2 responden Dokter gigi yang pengisian odontogramnya telah sesuai.

Penilaian singkatan penulisan odontogram hanya didapatkan 2 responden Dokter gigi yang penulisannya telah sesuai. Penilaian sim- 
bol-simbol odontogram didapatkan 8 responden Dokter gigi yang penulisannya telah sesuai. Seluruh responden Dokter gigi melakukan pengisian odontogram pada penilaian odontogram lainnya nomer 3.

Hasil penelitian ini sesuai dengan penelitian yang telah dilakukan oleh Hendry tahun 2009 bahwa pengisian catatan odontogram secara keseluruhan belum sepenuhnya memenuhi petunjuk pengisian odontogram yang seharusnya dilengkapi ${ }^{6}$. Sekitar $62 \%$ Dokter di india tidak melakukan catatan gigi atau jika ada dengan kualitas yang buruk ${ }^{8}$. Disejumlah Negara maju penulisan rekam medik gigi telah menjadi penting, beda halnya dengan negara berkembang penulisan rekam medik gigi masih sangat rendah?.

Tingkat kesadaran yang masih kurang menjadi penyebab utama penulisan rekam medik gigi jarang untuk dilakukan. Salah satu pendukung tingkat kesadaran yang masih kurang yaitu, Dokter gigi tidak mengetahui keberadaan pedoman dan sistem penulisan catatan gigi yang akurat dan terbaru. Adanya pedoman dan sistem penulisan catatan gigi dapat mendorong Dokter gigi untuk melakukan penulisan catatan gigi secara rutin? .

Ketidaklengkapan pengisian rekam medis terjadi karena Dokter lebih mengutamakan memberikan pelayanan, banyaknya pasien membuat Dokter berusaha untuk memberikan pelayanan cepat dengan keterbatasan waktu yang ada. Hal tersebut menyebabkan beban kerja Dokter semakin tinggi sehingga waktu yang digunakan untuk mengisi berkas rekam medik sangat terbatas ${ }^{10}$.

\section{KESIMPULAN}

Dari hasil penelitian dan pembahasan dapat disimpulkan bahwa penilaian odonto- gram Dokter gigi di dominasi penulisan dengan tidak lengkap sebanyak 39 responden, penulisan dengan kurang lengkap sebanyak 5 responden dan tidak didapatkan penulisan odontogram yang lengkap.

\section{DAFTAR PUSTAKA}

1. Simatupang $\mathrm{K}$, Suryani IR, Widyaningrum $\mathrm{R}$, Amalia R. Kualitas komunikasi dan kepuasan pasien dalam pelayanan radiograf kedokteran gigi RSGM Prof. Soedomo. Maj Kedokt Gigi Indonesia [Internet]. 2017;3(1):35. terdapat di: https:// jurnal.ugm.ac.id/mkgi/article/view/13201

2. Dewanto I. Gambaran Rekam Medik Gigi sebagai Posisi Sentral bagi Dokter Gigi di Yogyakarta Description of Dental Record as the Central Position among Dentists in yogyakarta. Mutiara Med. 2007;7(2):83-7.

3. Sudjana. Aspek Hukum Rekam Medis atau Rekam Medis Elektronik sebagai Alat Bukti dalam Transaksi Terapeutik. VeJ. 2017;3(2):35983.

4. Budi, A T. Peran restorasi gigi dalam proses identifikasi korban. J PDGI. 2014;63(2):41-5.

5. Plourd C. Forensic Dentistry. 2nd ed. Senn RD, editor. united states of america: CRC Press; 2010. 166-169 p.

6. Hendry. Gambaran data odontogram rekam medik gigi di balai pengobatan rumah sakit gigi dan mulut universitas sam ratulangi manado. 2009;2-5.

7. Kemenkes RI. panduan rekam medis kedokteran gigi. jakarta: bakti husada; 2015.

8. Devadiga A. What 's the deal with dental records for practicing dentists? Importance in general and forensic dentistry. 2014;6(1).

9. Abdalmawla A. Ali. Level of Awareness of Maintaining Dental Records among Dental Practitioners in Sirte: Are we Ready for Forensic Odontology? J Dent Dent Med. 2017;1(2):2-5.

10. Azizah LN. Perbedaan kelengkapan pengisian rekam medis berdasarkan status akreditasi pada puskesmas di wilayah dinas kesehatan kota surakarta. 2018. 